\title{
The effect of catabolic doses of corticosterone on heat production in the growing rat
}

\author{
BY PENNY COYER, M. COX, J. P. W. RIVERS AND D. J. MILLWARD \\ Nutrition Research Unit, Department of Human Nutrition, London School of Hygiene and \\ Tropical Medicine, 4 St Pancras Way, London NWI 2PE
}

(Received 13 August 1984-Accepted 3 January 1985)

\begin{abstract}
1. The effect of corticosterone treatment on energy balance and heat production was investigated in growing rats. Animals were treated with daily subcutaneous injections of a vehicle containing 0,50 or $100 \mathrm{mg}$ corticosterone $/ \mathrm{kg}$ for $5 \mathrm{~d}$.

2. Measurements of digestible energy intake and urinary energy losses showed that corticosterone treatment resulted in a depression of metabolizable energy intake due to elevated urinary energy losses resulting from massive glucosuria.

3. Measurements of the metabolizable energy intake and the change in carcass energy indicated that at $50 \mathrm{mg} / \mathrm{kg}$ energy deposition and heat production were reduced, whilst at $100 \mathrm{mg} / \mathrm{kg}$ energy deposition was completely abolished with heat production increased. Postprandial oxygen consumption was unchanged at $50 \mathrm{mg} / \mathrm{kg}$ and increased at $100 \mathrm{mg} / \mathrm{kg}$.

4. Factorial analysis of these results based on reported values for the energy cost of protein and fat deposition indicated that (a) the depression of total heat production at $50 \mathrm{mg} / \mathrm{kg}$ could be entirely accounted for by the concomitant suppression of growth, and (b) the elevation of total and postprandial heat production at $100 \mathrm{mg} / \mathrm{kg}$ reflected a specific influence of corticosterone on thermogenesis.

5. The significance of these findings is discussed in the light of reports that corticosterone in low doses suppresses heat production.
\end{abstract}

There is accumulating evidence for the participation of corticosterone in the regulation of heat production, although an unequivocal role for the hormone remains to be defined. It is well established that corticosteroids exert a profound inhibitory effect on growth in rodents. Growth suppression occurs when food intake is maintained (Bellamy, 1964) or even increased (Odedra et al. 1983), relative to controls. This raises the possibility that heat production is elevated. By contrast, the oral administration of corticosterone acetate to adult mice results in a suppression of heat production, so that increased energy deposition occurs even when treated mice are pair-fed to controls (Galpin et al. 1983a). It has been suggested that this reflects an effect of the hormone on thermogenesis in brown adipose tissue (Galpin et al. $1983 \mathrm{~b}$ ). In keeping with this suggestion, adrenalectomy of obese Zucker rats has been shown to reduce efficiency of food utilization to that of heterozygotes and restore the ability to increase heat production in response to excess energy intake (Holt et al. 1983; Marchington et al. 1983). Thus, whilst studies point to a role for corticosterone in the direct or indirect control of heat production, the direction of change is less certain. In the present paper, the quantitative effect of catabolic doses of corticosterone on heat production in the growing rat is reported, as measured both by comparative carcass analysis and oxygen consumption. A preliminary account of these results has already been presented (Coyer et al. 1984).

\section{MATERIALS AND METHODS}

The animals used throughout were male Lister-Hooded rats (OLAC 1976 Ltd, Oxfordshire). For 1 week before study and during the experimental period, rats were fed ad lib. a synthetic diet containing $200 \mathrm{~g}$ casein and $600 \mathrm{~g}$ carbohydrate $/ \mathrm{kg}$. Rats were individually caged at $26^{\circ}(12 \mathrm{~h}$ light-12 h dark cycle) and body-weight was recorded daily. Corticosterone (Sigma, Poole, Dorset) was administered subcutaneously in a vehicle containing $(\mathrm{g} / \mathrm{l})$ : 8 sodium chloride, 5 sodium cellulose, 9 benzyl alcohol as modified from Tomas et al. (1979). 
Urine energy losses. A preliminary experiment was undertaken to estimate the impact of corticosterone-induced glycosuria on the metabolizability of the digestible energy intake. Two groups of nine rats (groups A and B) were used (mean starting weight 105 (SE 1.0) g). In each group individual rats were allocated to one of three treatment groups (three rats per group), receiving 50 or $75 \mathrm{mg}$ corticosterone/ $\mathrm{kg}$ or vehicle only, daily for $7 \mathrm{~d}$. Group A rats were individually housed in metabolism cages and urine collected over $0.5 \mathrm{ml}$ Hibitane $(20 \mathrm{~g} / 1$ hydrochloric acid $(300 \mathrm{ml} / 1))$ each day on days 4-7 and stored at $-20^{\circ}$. Group B rats were caged on wire grids suspended over plastic trays and total spillage and faeces collected and separated. The energy contents of food and faeces were determined by ballistic bomb calorimetry (Miller \& Payne, 1959) of triplicate samples. Digestible energy intake was calculated as the difference between the gross energy content of food consumed (food fed minus spillage) and the gross energy content of the faeces. The collected urine from individual group A rats was pooled and briefly dried by rotary evaporation before bomb calorimetry.

Energy balance. Thirty-two weight-matched rats (mean starting weight 108 (SE 1) g) were used. Five rats were killed by chloroform anaesthesia at the outset of the experiment to provide baseline values for carcass composition. Eighteen rats were treated in groups of six with 50 or $100 \mathrm{mg} / \mathrm{kg}$ corticosterone or vehicle only, daily for $5 \mathrm{~d}$, then killed. Rats were caged on wire grids suspended over plastic trays containing a thin film of Hibitane $(20 \mathrm{~g} / \mathrm{l} \mathrm{HCl}(300 \mathrm{ml} / \mathrm{l}))$. Cages and wire grids were washed down daily with distilled water and the mixture of spilled food, faeces and urine removed and stored at $-20^{\circ}$. At the end of the experiment, the daily collections of faeces, spillage and urine from individual rats were pooled and thoroughly homogenized. Triplicate samples were analysed for energy content without previous drying. Total metabolizable energy intake was calculated as the difference between the energy content of food given and the energy content of the spillage, faeces and urine.

Energy deposition was measured as the increase in carcass energy over $5 \mathrm{~d}$. Frozen carcasses of the day 0 control rats and the day 5 experimental rats were finely ground in a Moulinex Chopper (Type 320), freeze-dried and reground before analysis for energy and crude protein (nitrogen $\times 6 \cdot 25$; Kjeltec auto 1030 analyser). Protein and energy gains in the experimental groups were calculated as the difference from day 0 controls. Energy gain as fat was calculated as the difference between total energy gain and energy gain as protein (assuming $23.8 \mathrm{~kJ} / \mathrm{g}$ protein). Total heat production was calculated as the difference between metabolizable energy intake and carcass energy gain.

On days 2-5 postprandial heat production was estimated on the remaining nine rats (three rats at each dose level) by measurement of $\mathrm{O}_{2}$ consumption in a closed-circuit calorimeter for $2-4 \mathrm{~h}$, starting at $6 \mathrm{~h}$ after the end of the feeding period, at $26^{\circ}$.

\section{Statistics}

Results are presented as means with their standard errors. Statistical comparisons between groups were made by analysis of variance, followed by Student's $t$ test for unmatched samples. Differences were considered statistically significant at $P<0.05$.

\section{RESULTS}

\section{Urine energy losses}

As reported by other workers, corticosterone was found to be without effect on digestible energy intake (Table 1). However, the proportion of food intake available for metabolism cannot necessarily be inferred from this measurement. Glucosuria and attendant polyuria are characteristic of animals treated with high doses of corticosterone and the quantitative 
Table 1. Effect of corticosterone ( $\mathrm{mg} / \mathrm{kg}$ per $\mathrm{d}$ ) on digestible energy intake $(\mathrm{DE} ; \mathrm{kJ} / \mathrm{kg}$ body-weight $t^{0 \cdot 75}$ per $d$ ) and urinary energy losses $\left(\mathrm{kJ} / \mathrm{kg}\right.$ body-weight $\left.{ }^{0.75} \mathrm{per} d\right)$

(Mean values with their standard errors)

\begin{tabular}{rrrrrr}
\hline & \multicolumn{2}{c}{ DE intake $(n 3)$} & & \multicolumn{2}{c}{ Urinary energy loss $(n 3)$} \\
\cline { 2 - 3 } \cline { 5 - 6 } Dose & Mean & SE & & Mean & SE \\
\hline 0 & 1102 & $26 \cdot 0$ & & $27^{\mathrm{a}}$ & $1 \cdot 3$ \\
50 & 1077 & $30 \cdot 9$ & & $370^{\mathrm{b}}$ & $9 \cdot 8$ \\
100 & 1102 & $37 \cdot 6$ & & $442^{\mathrm{c}}$ & $24 \cdot 1$ \\
\hline
\end{tabular}

a, b, e Means with different superscript letters were significantly different $(P<0 \cdot 05)$.

Table 2. Effect of corticosterone ( $\mathrm{mg} / \mathrm{kg}$ per $\mathrm{d}$ ) on the metabolizable energy intake ( $\mathrm{ME} ; \mathrm{kJ} / \mathrm{kg}$ body-weight ${ }^{0.75}$ per $d$ ) of rats used for the determination of total heat production (group 1 ) and measurement of oxygen consumption (group 2)

(Mean values with their standard errors)

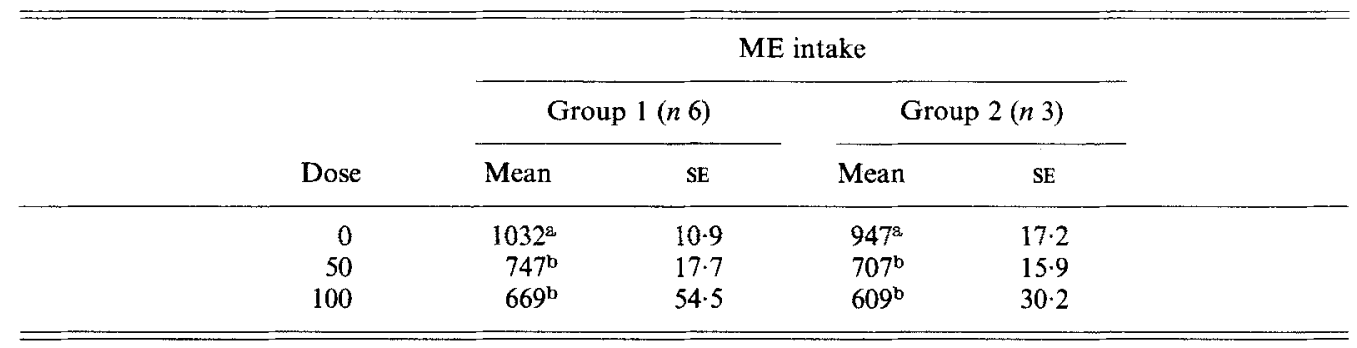

a, b Means with different superscript letters were significantly different $(P<0.05)$.

impact of urinary energy losses on the metabolizability of the diet has not previously been considered. As shown in Table 1, urine energy losses were found to increase with increasing dose of corticosterone. Precise calculation of metabolizable energy intake is precluded by the fact that the difficulty in accurately measuring digestible energy intake when rats are housed in metabolism cages meant that a separate group of rats was used for measurement of digestible energy intake. However, by comparison, whereas urinary losses were only $2.5 \%$ of the digestible energy intake, losses in the treated groups were up to sixteen fold higher.

\section{Energy balance}

The metabolizable energy intakes of the rats used for comparative carcass analysis and $\mathrm{O}_{2}$ consumption are shown in Table 2. For each dose level, differences between the energy intakes of these groups were not significant. However, as anticipated from the results obtained in the previous experiment actual metabolizable energy intake was reduced by corticosterone treatment, such that the metabolizable energy intake of rats receiving the higher dose was only $65 \%$ of the sham-injected controls.

As Fig. 1 shows, growth rate was markedly suppressed by corticosterone treatment; at both dose levels, animals lost weight during the course of the experiment. However, the relation of these changes to energy balance was obscured by marked changes in body composition with treatment. These are shown in Fig. 2. As expected for young rats, control 


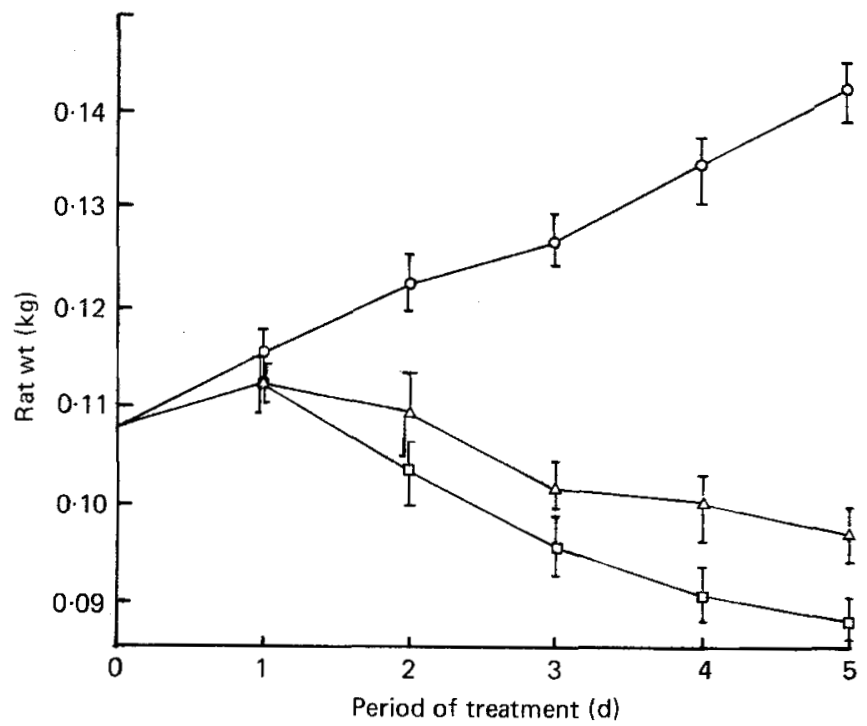

Fig. 1. Daily body-weights $(\mathrm{kg})$ of rats receiving $0(\mathrm{O}), 50(\triangle)$ or $100(\square) \mathrm{mg}$ corticosterone $/ \mathrm{kg}$ per $\mathrm{d}$. Values shown are means of six animals with their standard errors represented by vertical bars.

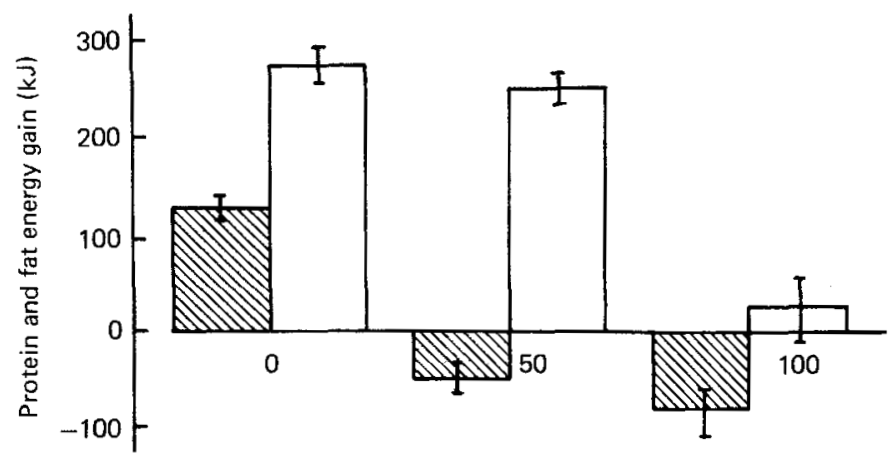

Corticosterone dose $(\mathrm{mg} / \mathrm{kg})$

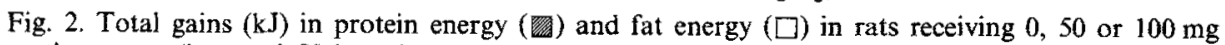
corticosterone $/ \mathrm{kg}$ per $\mathrm{d}$. Values shown are means of six animals with their standard errors represented by vertical bars.

animals deposited both protein and fat. The predominant effect of corticosterone treatment was a loss of body protein: rats receiving $50 \mathrm{mg} / \mathrm{kg}$ remained in overall positive energy balance despite this loss. At $100 \mathrm{mg} / \mathrm{kg}$ there was overall negative energy balance as a consequence of greater loss of carcass protein, possibly coupled with a reduced gain in carcass fat, although this was not statistically significant.

The effect of corticosterone on heat production is shown in Table 3. Compared with controls, total heat production was found to be depressed at $50 \mathrm{mg}$ corticosterone $/ \mathrm{kg}$ and elevated at $100 \mathrm{mg} / \mathrm{kg}$, both these differences being statistically significant. $\mathrm{O}_{2}$ consumption measured at $6 \mathrm{~h}$ after the cessation of feeding was found to be unchanged at $50 \mathrm{mg} / \mathrm{kg}$ and elevated at $100 \mathrm{mg} / \mathrm{kg}$. 
Table 3. Effect of corticosterone $(\mathrm{mg} / \mathrm{kg}$ per $d)$ on total heat loss over $5 \mathrm{~d}(\mathrm{~kJ} / \mathrm{kg}$ bodyweight ${ }^{0 \cdot 75}$ per $d$ ) and average oxygen consumption ( $\mathrm{VO}_{2}$, litres $/ 2 \mathrm{~h}$ per $\mathrm{kg}$ body-weight ${ }^{0 \cdot 75}$, days 2-5)

(Mean values with their standard errors)

\begin{tabular}{|c|c|c|c|c|c|c|c|c|}
\hline \multirow[b]{2}{*}{ Dose } & \multicolumn{2}{|c|}{ ME intake } & \multicolumn{2}{|c|}{ Energy gain } & \multicolumn{2}{|c|}{ Total heat } & \multicolumn{2}{|c|}{$\mathrm{VO}_{2}$} \\
\hline & Mean & $\mathbf{S E}$ & Mean & $\mathrm{SE}$ & Mean & SE & Mean & SE \\
\hline 0 & 1032 & $10 \cdot 9$ & $383^{a}$ & 18.6 & $649^{\mathrm{a}}$ & 19.8 & $2 \cdot 1^{d}$ & $0 \cdot 1$ \\
\hline 50 & 747 & $17 \cdot 7$ & $213^{b}$ & $21 \cdot 8$ & $534^{b}$ & $10 \cdot 8$ & $2 \cdot 2^{\mathrm{d}}$ & 0.1 \\
\hline 100 & 669 & $54 \cdot 5$ & $-67^{\mathrm{c}}$ & $34 \cdot 1$ & $746^{\mathrm{c}}$ & $30 \cdot 1$ & $2 \cdot 6^{\mathrm{e}}$ & 0.1 \\
\hline
\end{tabular}

$a, b, c, d, e$ Means with different superscript letters were significantly different $(P<0.05)$.

\section{DISCUSSION}

The effect of corticosterone on urinary energy losses was considerable. At the higher dose, measured urinary energy losses approached $40 \%$ of typical values for digestible energy intake and clearly, if overlooked, such losses would dramatically alter the interpretation of results. Such findings underline the necessity to consider the quantitative, rather than qualitative impact of treatments on urine composition whenever the state of energy balance is a primary objective of study or a potentially confounding variable in the interpretation of results. In the present study it is probable that, in addition to glucosuria, ketonuria was also induced by corticosterone treatment. Despite precautions of collecting urine in acidic solution (Boedihardjo, 1982) and storing it at low temperatures, storage and particularly drying would result in losses of acetone (through volatilization) and a proportion of acetoacetate (via spontaneous degradation to acetone). Urinary energy losses were therefore, probably, slightly underestimated. However, since acetone and acetoacetate are not major contributors to total ketone body excretion during ketosis, such errors are unlikely to account for more than $5 \%$ of intake. These losses were further minimized in the second experiment since the high solids content of the pooled spillage and excreta permitted bomb calorimetry without previous reduction of moisture content.

The glucosuria undoubtedly reflects the hyperglycaemic response to exogenous corticosterone. This in turn results from the simultaneous effect of corticosterone in suppressing peripheral glucose utilization (Munck, 1971) and stimulating gluconeogenesis, despite a continuing supply of dietary glucose. Apparently, the glucose cannot be disposed of in peripheral tissues such as muscle or adipose tissue, even though there is marked hyperinsulinaemia (Tomas et al. 1979; Odedra et al. 1982, 1983), because corticosterone antagonizes insulin-mediated glucose transport.

In considering the effect of corticosterone treatment on heat production, one approach to the evaluation of the results is in the context of the classical view of energy balance, in which it is assumed that the heat production of young animals varies in association with the extent and composition of growth. Overall changes in heat production in response to corticosterone will, therefore, reflect in part the effect of corticosterone on tissue deposition an effect which may be entirely divorced from any specific influence of corticosterone on thermogenesis. In order to dissociate these components of heat production, we have analysed the results in accordance with the factorial partitioning of energy balance (Kielanowski \& Kotarbinska, 1970):

$$
H=R+k_{p} P+k_{f} F,
$$


Table 4. Effect of corticosterone $(\mathrm{mg} / \mathrm{kg}$ per $d$ ) on the distribution of heat production $\left(k J / k g\right.$ body-weight $t^{0.75}$ per $\left.d\right)$ between the cost of fat $\left(\mathrm{k}_{\mathrm{f}}\right)$ and protein $\left(\mathrm{k}_{\mathrm{p}}\right)$ deposition and maintenance $(\mathrm{R})$

\begin{tabular}{rcccccc}
\hline Dose & $\begin{array}{c}\text { Heat } \\
\text { production }\end{array}$ & $\begin{array}{c}\text { Protein } \\
\text { gain }\end{array}$ & Fat gain & $k_{p}$ & $k_{f}$ & $R$ \\
\hline 0 & 649 & 121 & 262 & $151 \cdot 2$ & $65 \cdot 5$ & $432 \cdot 3$ \\
50 & 534 & - & 270 & - & $67 \cdot 5$ & $466 \cdot 5$ \\
100 & 746 & - & 28 & - & $7 \cdot 0$ & $711 \cdot 0$ \\
\hline
\end{tabular}

where $P$ and $F$ represent energy gain as protein and fat respectively, and heat production $(H)$ is considered to be partitioned between three components, i.e. $k_{p}$, the heat production statistically associated with gaining protein (the 'cost' of protein deposition); $k_{f}$, the heat production statistically associated with gaining fat (the 'cost' of fat deposition), and $R$, the residual amount of heat production which occurs at zero energy deposition ('maintenance').

Table 4 shows the results of using this model in the analysis of results obtained. To account for the dependence of heat production on body size, all variables have been expressed in relation to metabolic body size $\left(\mathrm{kg}\right.$ body-weight $\left.{ }^{0.75}\right)$. The heat production associated with growth (Table 4 ) has been calculated assuming values for $k_{p}$ and $k_{f}$ of 1.25 and $0.25 \mathrm{~kJ} / \mathrm{kJ}$ deposited respectively (Pullar \& Webster, 1977). These components of heat production were subtracted from total heat production to derive a value for $R$. This term is usually considered to represent the heat production occurring at maintenance, and the value derived in this way for controls agrees satisfactorily with the mean interspecies maintenance requirement (Payne \& Waterlow, 1971). In treated animals, the solution for $R$ represents that proportion of total heat production which cannot be accounted for by the usual 'costs' of depositing the observed tissue gains. This component of heat production is seen to be unchanged relative to controls at $50 \mathrm{mg}$ corticosterone $/ \mathrm{kg}$, but markedly elevated at $100 \mathrm{mg} / \mathrm{kg}$. This analytical approach and conclusion are supported by the results obtained for $\mathrm{O}_{2}$ consumption, which was measured $6 \mathrm{~h}$ after the cessation of feeding when the impact of growth costs on heat production can be expected to approach a minimum. Heat production was unchanged relative to controls at $50 \mathrm{mg}$ corticosterone $/ \mathrm{kg}$ and elevated at $100 \mathrm{mg} / \mathrm{kg}$.

Although the previously mentioned analysis clarifies the relation between heat production and growth, it does not explain the mechanism by which corticosterone influences protein and energy deposition. In this respect, some aspects of corticosterone action are well established. Both dose levels given in the present study have a specific catabolic influence on protein deposition in muscle, which involves a suppression of protein synthesis (Millward et al. 1976) through its inhibitory effects on ribosomal RNA synthesis (see Millward et al. $1983 a$ ) and its blockage of insulin's stimulation of translation (Millward et al. 1983b). In addition, it can induce a transient increase in muscle protein degradation (Odedra $e t$ al. 1983). As a result, substrates can be made available for hepatic gluconeogenesis which is stimulated by the hormone.

The effect of corticosteroids on fat deposition are less clear. Whilst there is a well-defined role for the hormone in fat mobilization through the stimulation of lipolysis, corticosteroid treatment of humans can lead to an increase in adipose tissue deposition and obesity (Royal College of Physicians, 1983). Certainly, in the present study, whilst the deposition of fat was almost completely suppressed at $100 \mathrm{mg} / \mathrm{kg}$, at $50 \mathrm{mg} / \mathrm{kg}$, fat deposition was comparable with that of controls. One explanation for this relates to the hyperinsulinaemia which accompanies corticosteroid treatment (Tomas et al. 1979; Odedra et al. 1982, 1983). 
This response means that both anabolic and catabolic stimuli for fat deposition would be present simultaneously and the net effect would probably depend on the relative concentrations of the insulin and corticosterone. It would appear from the present study that at the lower dose, the hyperinsulinaemia is dominant as far as fat deposition is concerned and this may partially explain the effect of corticosteroids on fat deposition in humans. However, because adrenalectomy inhibits the further development of obesity in obese strains of rodents (Bray \& York 1979; Bray, 1982), a role for the hormone has been sought in the suppression of thermogenesis. Thus, Galpin et al. (1983a) have reported that in adult mice, chronic administration of corticosterone increases fat deposition and metabolic efficiency and this is related to a specific reduction of thermogenesis in brown adipose tissue, associated with reduced cytochrome $c$ oxidase (EC 1.9.3.1) activity and decreased GDP binding (Galpin et al. 1983b). The nature of this effect was not, however, completely clear, since corticosterone did not prevent the increased GDP binding of brown adipose tissue in cold-stressed mice. Clearly, these results are in marked contrast to our findings. However, the study of Galpin et al. (1983a) was conducted on mice and there is some evidence that the response to corticosterone is dependent on species and strain (Hausberger \& Hausberger, 1960). Another explanation may be the dose levels. According to Steele (1975), the replacement dose for an adrenalectomized rat is $2-5 \mathrm{mg}$ corticosterone $/ \mathrm{kg}$ per $\mathrm{d}$, so that our doses are at least ten to twenty times replacement levels. This is supported by the findings of Tomas et al. (1979) who measured the plasma levels of corticosterone in rats treated with various doses of the hormone and showed that at the doses we have used, plasma levels were elevated to the very high concentrations observed in 4-d fasted young rats (Millward et al. 1983b). Thus, our doses are fifteen to thirty times higher than those used by Galpin et al. (1983a), which were designed to be three times replacement level. It is therefore possible that the action of corticosterone may be biphasic, acting to suppress heat production at low doses and to elevate it at high doses.

There are several features of the response to high doses of corticosterone which could influence heat production. In contrast to most situations where growth suppression is associated with reduced metabolic activity, the present case may well be an exception. For example, as far as protein synthesis is concerned, although muscle protein synthesis is depressed in rats treated with $10 \mathrm{mg}$ corticosterone/d, liver protein synthesis is increased by $60 \%$ (Odedra et al. 1984), and the overall rate of protein synthesis is not depressed relative to that attained in control growing rats (P. Coyer, unpublished results). Thus, to the extent to which protein synthesis contributes to growth costs, these costs will still occur in the treated rats although they are unlikely to be responsible for the increased heat production.

To some extent increased thermogenesis might be anticipated as a consequence of an altered pattern of substrate utilization. The suppression of protein deposition without a reduction in intake means that the amount of protein oxidized must be increased in the treated rats. Since the number of high-energy phosphate bonds produced per molecule of oxygen consumed (P:O value) for protein utilization is less than that for other fuels (McGilvery, 1970), oxygen consumption would be expected to rise for given metabolic work. Moreover, the efficiency of protein oxidation is considered to be further reduced when amino acids are oxidized via the intermediate production of glucose rather than directly and, as discussed, gluconeogenesis is likely to be stimulated by corticosterone. However, the difference in ATP yield given by these alternatives may have been exaggerated (Livesey, 1984) and our calculations indicate that, even at the highest dose, changes in the pattern of fuel utilization could not account for more than $5 \%$ of the increased heat production. Furthermore, the amount of protein oxidized at the higher dose was not much greater than that oxidized at the medium dose, yet heat production was considerably increased.

The hyperinsulinaemia induced by corticosterone treatment (Tomas et al. 1979; Odedra et al. 1982, 1983) could stimulate thermogenesis. Increased heat production might be 
anticipated in view of the involvement of insulin in catecholamine-mediated alterations in brown adipose tissue thermogenesis (Rothwell \& Stock, 1981; Rothwell et al. 1983). It is, however, uncertain as to whether insulin could be effective in the present case, since, as already indicated, at least some insulin-sensitive processes (glucose uptake and muscle protein synthesis) are partially blocked by a high level of corticosterone (Munck, 1971; Millward et al. 1983 b). Conversely, the complete suppression of insulin-dependent energy deposition in muscle and adipose tissue at the high dose of corticosterone is likely to increase levels of free fatty acids, which in turn could directly stimulate thermogenesis in brown adipose tissue (Locke \& Nicholls, 1981).

A role for thyroid hormones in the response to corticosterone is also plausible. Despite evidence that corticosteroids may suppress peripheral monodeiodination of thyroxine (Chopra, 1981), free 3,5,3'-triiodothyronine $\left(\mathrm{T}_{3}\right)$ is elevated in adrenalectomized rats treated with catabolic doses of corticosterone (Odedra et al. 1984) and, in addition to any direct effects on heat production, elevated $\mathrm{T}_{3}$ levels may potentiate $\beta$-adrenergic thermogenesis (Rothwell et al. 1982). Finally, a more proximate involvement of corticosterone cannot be excluded. It has long been known that corticosterone treatment stimulates lipogenesis and glycogenesis in brown adipose tissue (Lachance \& Page, 1953) and corticosteroid receptors are present in this tissue. In addition, corticosteroids may regulate $\beta$-adrenoreceptor number and affinity in the rat (Hedburg, 1983) again raising the possibility that part of the response involves catecholamine-mediated events. This is supported by our recent observations that rats treated with $100 \mathrm{mg}$ corticosterone $/ \mathrm{kg}$ for $6 \mathrm{~d}$ show an exaggerated increase in $\mathrm{O}_{2}$ consumption in response to norepinephrine treatment $(600 \mu \mathrm{g} / \mathrm{kg}$ subcutaneously; maximum increase $46.1 \%$ (SE 1.07) treated $v .36 .4 \%$ (SE 0.97) controls, $P<0.01)(\mathrm{P}$. Coyer, unpublished results).

The present findings are consistent with the growing body of evidence in support of a role for corticosterone in the regulation of heat production. However, whereas the suppression of heat production by corticosterone has hitherto been emphasized, these results clearly demonstrate that this picture is incomplete. As such, the changing direction of response according to experimental design affords a potential model for elucidating the mechanisms through which corticosterone exerts its effects.

This work was generously supported by a grant from the British Diabetic Association and by a London University Sanderson Wells Studentship in Nutrition awarded to P.C. We are grateful for the technical assistance of Mr Peter Donachie.

\section{REFERENCES}

Bellamy, D. (1964). Journal of Endocrinology 31, 83-84.

Boedihardjo, S. (1982). Studies on changes in acid and ketone body excretion in obese patients in starvation and on low energy diets. MSc Thesis, London School of Hygiene and Tropical Medicine.

Bray, G. A. (1982). Proceedings of the Nutrition Society 41, 95-108.

Bray, G. A. \& York, D. A. (1979). Physiological Reviews 59, 719-809.

Chopra, I. J. (1981). Monographs on Endocrinology 18, 5915-6430.

Coyer, P. A., Cox, M., Rivers, J. P. W. \& Millward, D. J. (1984). Proceedings of the Nutrition Society 43, 75 A.

Galpin, K. S., Henderson, R. G., James, W. P. T. \& Trayhurn, P. (1983a). Proceedings of the Nutrition Society 42, $159 \mathrm{~A}$.

Galpin, K. S., Henderson, R. G., James, W. P. T. \& Trayhurn, P. (1983 b). Biochemical Journal 214, $265-270$.

Hausberger, F. X. \& Hausberger, B. C. (1960). American Journal of Clinical Nutrition 8, 671-681.

Hedburg, A. (1983). Acta Medica Scandinavica 672 (Suppl.), 7-15.

Holt, S., York, D. A. \& Fitzsimons, J. T. R. (1983). Biochemical Journal 214, 215-223.

Kielanowski, J. \& Kotarbinska, M. (1970). European Association for Animal Production Publication 13, $145-148$.

Lachance, J. P. \& Page, E. (1953). Endocrinology 52, 57-64.

Livesey, G. (1984). British Journal of Nutrition 51, 15-28.

Locke, R. M. \& Nicholls, D. G. (1981). FEBS Letters 135, 249-252. 
McGilvery, R. W. (1970). Biochemistry: A Functional Approach. Philadelphia and London: W. B. Saunders. Marchington, D., Rothwell, N. J., Stock, M. J. \& York, D. A. (1983). Journal of Nutrition 113, $1395-1402$. Miller, D. S. \& Payne, P. R. (1959). British Journal of Nutrition 13, 501-508.

Millward, D. J., Bates, P. C., de Benoist, B., Brown, J. G., Cox, M., Halliday, D., Odedra, B. N., \& Rennie, M. J. (1983a). IVth International Symposium on Protein Metabolism and Nutrition V1, European Journal of Animal Production, no 31, pp. 69-96.

Millward, D. J., Garlick, P. J., Nnanyelugo, D. O. \& Waterlow, J. C. (1976). Biochemical Journal 156, $185-188$. Millward, D. G., Odedra, B. \& Bates, P. C. (1983 b). Biochemical Journal 216, 583-587.

Munck, A. (1971). Perspectives in Biology and Medicine 14, 265-289.

Odedra, B., Bates, P. C. \& Millward, D. J. (1983). Biochemical Journal 214, 617-627.

Odedra, B., Cox, M. \& Millward, D. J. (1984). Proceedings of the Nutrition Society 43, 13 A.

Odedra, B., Dalal, S. \& Millward, D. J. (1982). Biochemical Journal 214, 363-368.

Payne, P. R. \& Waterlow, J. C. (1971). Lancet ii 201-221.

Pullar, J. A. \& Webster, A. J. F. (1977). British Journal of Nutrition 37, 355-367.

Rothwell, N. J., Saville, E. M. \& Stock, M. J. (1982). American Journal of Physiology 243, R339-R346.

Rothwell, N. J., Saville, E. M. \& Stock, M. J. (1983). American Journal of Physiology 245, $160-165$.

Rothwell, N. J. \& Stock, M. J. (1981). Metabolism 30, 673-678.

Royal College of Physicians (1983). Journal of the Royal College of Physicians (London) 17, 5-65.

Steele, R. (1975). Handbook of Physiology, Section 7, vol. 6, pp. 135-167. Baltimore MD: Williams and Wilkins. Tomas, F. M., Munro, H. N. \& Young, V. R. (1979), Biochemical Journal 178, $139-149$. 